\title{
The role of woody plants in the formation of figurative and symbolic structure of memorial parks
}

\author{
Nadiia Oleksiichenko ${ }^{1}$, Nadiia Gatalska ${ }^{1}$, Mariana Mavko${ }^{1}$, Oleksandr Ostapchuk ${ }^{2}$, \\ ${ }^{I}$ National University of Life and Environmental Sciences of Ukraine, Kyiv, Ukraine; \\ ${ }^{2}$ Uman National University of Horticulture, Uman, Ukraine
}

\begin{abstract}
The article presents the results of the research of the role of plants in the formation of the figurative and symbolic structure of the war memorial parks. It is determined that tree plants can play a role of the the indirect means of expressing the ideological load during different periods of the year. Some species of deciduous shrubs play this role only in autumn due to the red colour of not only fruits but also of foliage, in particular, the Viburnum opulus L., which is common in the war memorial parks in Kyiv, which emphasizes their ideological load due to the fruit and leaves in autumn colouring, as well as the symbolic meaning of this plant for Ukrainians. In winter, the plant act as the means of expressing the ideological load of the war memorial parks due to the shape and colour of the crown, branches, fruits (Rhus typhina L., Cornus mas 'Sibirica', Viburnum opulus L., Sorbus aucuparia 'Pendula'). Based on the results of an expert assessment of Kyiv memorial parks, the peculiarities of the use of woody plants in the formation of figurative and symbolic structure of the war memorial parks of Kyiv are revealed and a structural scheme is developed according to the semiotic levels of perception as per Barabanov (2002). It is discovered that using of plants is most widely represented in parks, which is based on the sign level of perception (collective unconscious) caused by the peculiarities of perception and interpretation of the lines, form and colour of the plant. In particular, within the researched parks, it was revealed that both the positive and the negative effects of the shape, size, colour and texture of the plants influence the perception of the memorial architectural components. When using symbols in the formation of figurative and symbolic structure of the park using plants two approaches to the formation of plant composition are revealed. The first is based on the use of symbolical for Ukrainian species of plants (Viburnum opulus L., Sorbus aucuparia L.), while plant groups are mono-species independent components of the composition. In the second approach, the matching of plants is based on the symbolic meaning of their morphological characteristics. In this case, the plants are located next to the memorial architectural objects as secondary components to enhance emotional influence and increase the information characteristics of the memorial. This approach to the use of plants for the formation of figurative and symbolic structure of the park is based on the symbolic level of semiotic units of perception, according to Barabanov (2002), which is determined by the sociocultural context that is formed within a certain social, historical period and territory.
\end{abstract}

Keywords: symbolism of plants, park composition

Introduction

Park landscape, as part of the subject-spatial urban environment, inextricably linked to its functional and figurative-information system and along with architecture is the means of information that was laid down during its formation, is actualized during perception and affects consciousness [8]. This creates a "tangible landscape" (the concept as per Lynch [17]) - a tangible environment that affects interpersonal communication, focuses attention on its importance for human comfort and is expressed in sounds, aromas that can both promote and interfere with communication.

The simplicity of the means of information communication, in particular the using of the simplest elements that organize the architectural form and influence the person emotions is the important characteristic of understanding and correct interpretation of information [8]. Le Corbusier [15] emphasized namely the importance of the elementary forming elements of architectural forms and the need to study their influence on the

perception of man. Thus, the concept of informativity of the urban environment relates both to direct means of information [17], and to the system of symbols, figurative meaning, signs $[15 ; 26 ; 2 ; 13]$, which form a certain semiotic structure. The symbolic and sign system is characterized by special forms in the park landscape, and it is due to the biological nature of its components and the continuity of the development of the park three-dimensional composition. The regular transformation processes of the landscape components complicate the process of designing the figurative and symbolic structure of the park, and its research. In this context, it is important to mention about the research of Yilmaz, Özgüner \& Mumcu, [27], where authors point out the possibility of studying the landscape aesthetics in terms of formal and symbiotic aesthetics and consider the aesthetic assessment of the parks and greenspaces as a process oriented towards perception, both in form and with a symbol - two variables of the general assessment. 
These studies are of great importantance in the study of memorial parks that provide a connection to the past generations by means of the sign, symbolic and semantic system, which shows itself first of all in the planning structure, monumental decoration and general composition. The most semiotic approach to the formation of the figurative meaning of park landscape, as well as the demonstration of "collective consciousness" is observed in the memorial parks of war themes, the content component of which is based on the sign, figurative and symbolic level of perception. In particular, Oleksiichenko et al. [18] in the research of war memorial parks, point out the direct and indirect means of expressing the ideological load of the park, which can both contribute into correct interpretation of the information and symbolic meanings laid down during park formation, and level them.

The form of the direct means of expression directly reflects the intended figurative meaning, the idea of the object, and the indirect means of expression indicate the ideological content and can increase the meaning of direct means. Indirect means act on the basis of allegories embedded in their artistic image (the abstract concepts, their representation through the close associations, concrete images and objects), symbols (images of the maximum degree of generalization and expressing an idea or a original peculiarity of a certain event or phenomenon). These means are aimed at activating relevant associations from visitors (concepts that appear when referring to another one, a subjective image of an objective connection between objects and phenomena) and, thus, "are being read" while observing [18]. In the context of the using of allegories and the system of symbols, it is worth noting that the basis for their perception and understanding is "collective memory", which is formed mainly in the result of sociogenesis. In particular, Jankovic [13] notes that the architectural form of a man-made memorial object is a materialization of collective memory. At the same time, plants in the memorial parks usually act as indirect means of expressing the ideological load due to symbolism and associative perception of forms and colours. When choosing a tree or shrub for the dominant of plant composition - take into account the symbolic meaning of plants traditionally formed in some society, for example of genera Quercus L., Cedrus Trew., Platanus L. symbols of power and strength; Populus alba 'Pyramidalis', Populus nigra var. italica Münchh. trees of eternal memory [18].

Along with the symbolic meaning of plants the morphological characteristics, which are aimed at activating of associative perception, are of great importance as well. In particular, trees and shrubs that have a weeping crown, as well as plants with dark foliage, are used to emphasize the sense of sorrow and mourning. In addition, the "tree height" and "height of vegetation" are important characteristics of landscapes influencing human perception [9, 21, 16]. Galev, Gurkova \& Galev [7] emphasize the importance of plants for the perception of memorials mentioning the integrity of the perception of the monument and the surrounding plants.

An important aspect of studying the park landscape as a figurative and symbolic structure is the analysis of aesthetic preferences of visitors, in particular the influence of plantings on the aesthetic quality of landscapes. In this context, the research of Hofmann et al. [11] should be noted, where the features of the landscape that affect the high aesthetic assessment of professionals ("planners") and visitors were discovered. In particular, the high level of artificiality and contrast (high and low) levels of closure and prospects were good predictors of the aesthetic advantages of non-specialists.

According to the research Fuller et al. [6] it was revealed that biodiversity increases the aesthetic quality of green spaces and, although usually not considered intentionally positively associated with the aesthetic preferences of the landscape $[16 ; 14 ; 4]$. However, other authors $[25 ; 10]$ noted differences in the perception of species diversity between experts and non-professionals.

The value and features of the plants composition within park areas were studied by Polar \& Akay [20], who identified the relationship between the visual quality of park landscapes and: the color of the composition of plants (harmony among foliage, flowers and stems of individual plants); the form (the outline) of the composition of plants (harmony among trees, shrubs and flowers with their forms); a variety of plants. In addition, the authors found that the absence of shrubs negatively affects the aesthetic assessment of the landscape [20]. Despite the great impact of seasonal dynamics of plants on the image of the landscape [27], studies that draw attention to the volatility of plants during the growing season in terms of formal and symbolic aesthetics and perceptions are limited. In this context the research of Thorpert \& Nielsen [23] should be noted, who studied the relationship between the species diversity of plants communities, its colors and positive evaluation of the landscape and found that the most positive assessment of landscapes were noted in summer and autumn, and the lowest - in winter. It should be highlighted that the research was carried out directly in the environment, rather than using a photo that is also rarely encountered in the context of attracting respondents.

So, along with the fact that the plant is a subsidiary element of landscape expression of ideological load object, they are considered to be a 
particularly powerful factor in the perception of visual quality landscape that is highlighted by a number of researchers [16;23; 20;7; 27]. Such circumstances make it expedient to analyze the peculiarities of the use of plantations in the context of the informational and cognitive approach to studying the aesthetics of the park environment, as well as their influence on the formation of the figurative and symbolic structure of the memorial park.

The purpose of the research is to analyze the role of tree plantations in shaping the figurative and symbolic structure of the environment of memorial parks, as well as their influence on the aesthetic perception of park landscapes.

\section{Materials and methods}

The methodological basis for the study is the interactionist paradigm [19], in which the aesthetic qualities of objects and patterns of perception are determined by the survey of respondents in combination with an expert assessment. The expert assessment included an analysis of the compositional integrity and significance of plants in shaping the figurative and symbolic structure of the memorial parks in Kyiv. The purpose of involving respondents was to identify the features of the perception of plants and their impact on the formation of general-landscape emotional image of the landscapes by the parks visitors.

The research is based on Thorpert \& Nielsen [23], Dupont et al. 2014 [5], Hofmann et al. [11] Shelby \& Harris [22], however, has significant differences, in particular, a comparative analysis of the peculiarities of the perception of the park environment landscapes using different methods of conducting research, as well as allowing respondents to independently determine the factors influencing their assessment, instead of using semantic differential scales.

\section{Characteristics of research objects}

The research was conducted within the framework of Kyiv war memorial parks (3 objects) during 2012-2018, namely: Slava Park, Peremoha Park and Pechersk Landscape Park. Parks are located in different parts of the city (Fig. 1), created in the second half of the twentieth century and devoted to the events of the Second World War. The main differences between the researched parks include a significant difference in the area of the territories, the correlation of functional zones, as well as the planning and compositional construction of the three-dimensional structure of the park environment.

The materials for the research were the results of a comprehensive assessment of the territory of the Kyiv war memorial parks, including the use of field and analytical methods. The analysis of the cultural and historical significance of the experimental object was carried out by the monographic method, the town-planning characteristic - the cartographic method.

Expert evaluation is based on the principles of the environmental perception of the landscape, as well as the concepts of experimental psychology Holovey \& Hornova [12], which corresponds to the provisions of the system approach and coincides with the general trends in modern scientific research.

\section{Investigation of peculiarities of park landscapes perception by respondents}

To study the aesthetic qualities of the park environment, as well as to reveal the peculiarities of the perception of plants and their influence on the formation of a landscape of the nature of landscapes by visitors of parks among the memorial parks of Kyiv, the territory of the Slava Park was chosen as the research object with an area of 19.4 hectares located in the central part of the city. The park is the object of nature reserve fund of Ukraine as a parkmonument of landscape art of local significance. Within the park, there are 24 locations for the assessment of landscapes (Fig. 1), which are presented in 46 photos. Locations and photos were selected in accordance with generally accepted methods of conducting such studies (Daniel \& Boster [3]), in particular those used in Hofmann et al. [11], Polat \& Akay [20], and more. The study involved 25 participants aged 22-25 years -7 men and 18 women from different regions of Ukraine.

\section{Photographing and order of the research}

Since the study involves identifying features of the perception of park landscapes during the growing season. In particular, photographing of park landscapes was carried out during August 2017 (to illustrate the summer features of the park environment) and in October 2017 (to illustrate the autumn features of the park environment) in the sunny weather from $1 \mathrm{pm}$ to $4 \mathrm{pm}$, including the human factor in photographs. For photography, a semi-professional digital camera with a resolution of 20.1 million pixels. Photos are printed in $10 \times 15$ format (matte finish).

\section{Surveys and results analysis}

Describing the methods for determining the aesthetic preferences of respondents, it is advisable to note two approaches. The basis of the first is a comparative analysis of the aesthetic assessment of the landscape, obtained as a result of the survey of the respondents and parameters of the components of the landscape.

In this case, the parameterization of the components is carried out by experts in accordance with the purpose of the study, and photographs are used as models (including panoramic [20]). 


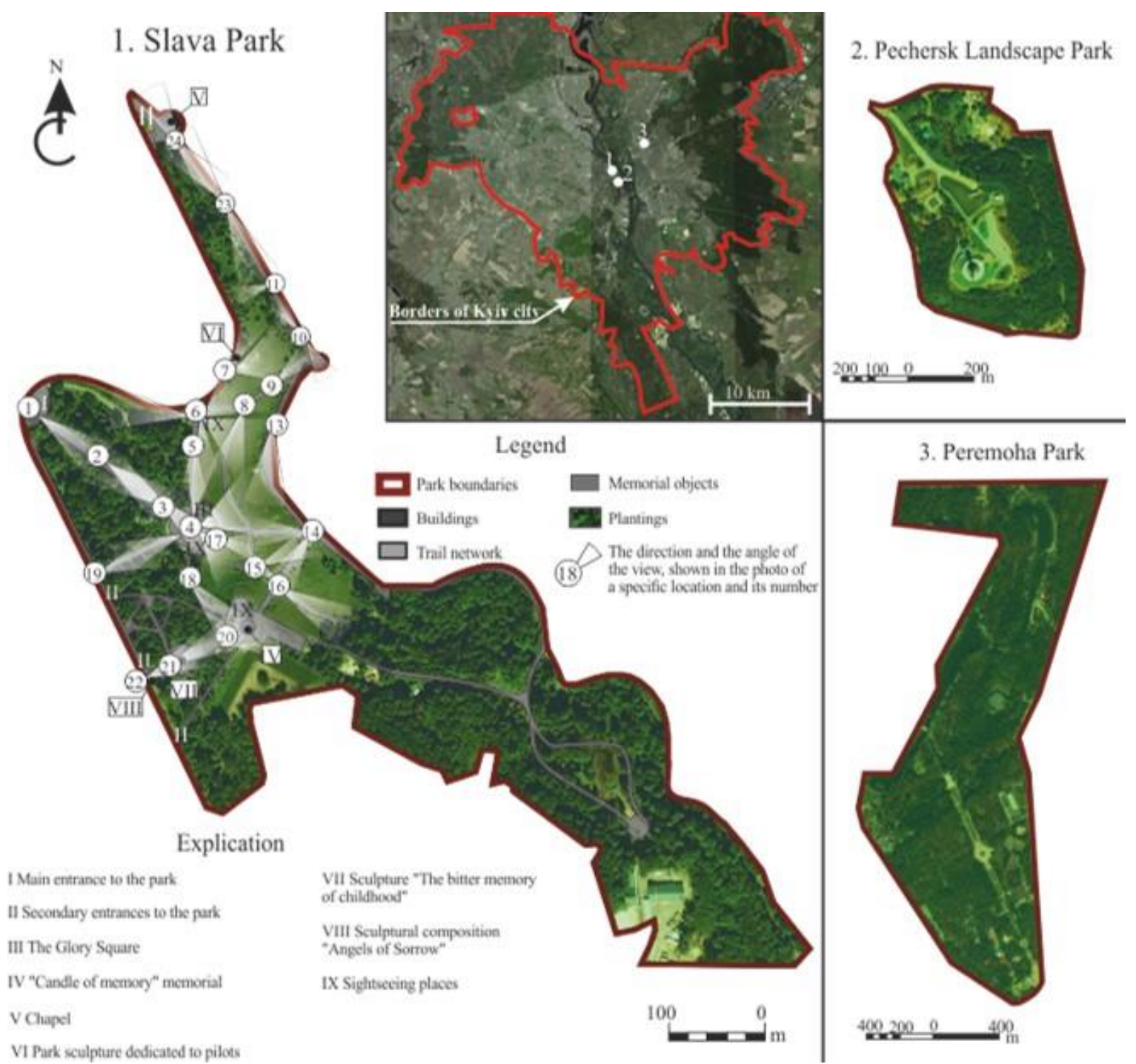

Fig. 1. The location of war memorial parks in Kyiv. The locations scheme in the Slava park, which were used to evaluate the aesthetic appeal of the park and the angles of view that are reflected in the photographs.

The second is based on the use of the semantic differential [11].

In the course of the study, both of the above methods were applied, however, the parameters of the park environment components were not carried out by experts to perform the tasks. Instead, the respondents were offered to independently substantiate the signs of the landscape, which are positive and increase their aesthetics or reduce it and can be defined as negative. The signs could include both the material components of the landscape and the associative notions and feelings that should be noted in the appropriate column opposite the photo number (substitution method) after evaluating a particular landscape on a 10-point scale, where 10 is the highest score. The expediency of the free choice of respondents for positive and negative signs of the park environment is conditioned by the need to determine the "readability" of the information structure of the park environment of the research object, as well as determining the role of plantations in shaping the overall landscape of the respondents' emotional reactions. The methodology used by Osychenko [19] to determine the aesthetic preferences of the urban environment was taken as a basis.

\section{Research results}

Expert assessment of composition structure of research objects and peculiarities of plants using in the formation of their figurative and symbolic structure

The first stage of the study was a complex analysis of researched objects based on an expert assessment, during which 123 species, 62 cultivars of woody plants were represented in the researched parks. The significant number of introduced plants among the park greenery were found, which are represented by species (106) and their cultivars (14). Along with the importance of the impact of species 
diversity on landscape aesthetic (Polar \& Akay [20]), the plant assortment does not make clear understanding of the compositional integrity of the object, as well as their role in creation of figurative and symbolic structure. Thus, the study of these aspects was done within the territory of Kyiv memorial parks.

The compositional structure of the Pechersk Landscape Park, especially within the territory of National Museum of the history of Ukraine in the Second World War, is harmonious as there are no components of the park space that disturb its integrity. Architectural elements and the elements of trail network (avenues, squares) are dominant, and plantings are subjected to them and highlight their compositional and ideological significance. Although the plant species diversity of the memorial complex is rather poor, however, the used species and cultivars of woody plants express the themes of the object. For example, small groups of Picea pungens 'Glauca', Picea pungens Engelm., in combination with Juniperus sabina L. are harmoniously located along the main alley and around the square; along the slope of the alley to "Roads of Life", a line of plantings from Viburnum opulus L. is growing, as well as around the bowl "Eternal Flame".

Other plant groups of the park are located behind the memorial on the slopes, without closing the views and emphasizing on the park theme, and also with no contradiction. However, the drawback is the monotony of plant composition and seasonality of its changes during the flower exhibitions in the park.

For parks with compositional unity it is expedient to include the Slava Park, the composition center of which is a monument of Glory. It is a 27-meter obelisk on the grave of an unknown soldier in the center of the Glory Square. From the entrance to the monument there is a wide alley, framed on both sides by the Carpinus betulus L. hedge. Along the Heroes' Alley there are 34 burial grounds of soldiers of different ranks. The Holodomor Victims Memorial is equally dominant in the park composition. The memorial includes three main parts: the "Candle of Memory", the Hall of Memory and the "Black Boards" Alley, with the names of the settlements affected by the Holodomor of 1932-1933. The planning structure of the park is determined by the compositional dominants, which emphasize its memorial purpose.

The park plants are represented mainly by deciduous woody groves from Aesculus hippocastanum L., Acer platanoides L., Tilia cordata Mill. etc., especially in the lower part of the park, and regular style compositions of coniferous plants and bosquets from Carpinus betulus L. The latter have an important composite value in forming the figurative and symbolic structure of the park, because they perform a number of functions aimed at emphasizing the ideological and historical significance of memorial architectural components, namely: formation of the view for the obelisk of Glory; visual isolation of the Heroes' Alley from the rest of the park area is to focus attention on the information content; creation of a closed space along the central alley of the park to increase the emotional influence of the obelisk of Glory at the exit to the Glory Square, which opens a view of the city.

The Guelder-rose Grove, which is planted in the zone of the Holodomor Victims Memorial Complex (locations 20, 21 in Fig. 1), and in the north-western part of the park along the walkway to the chapel (location 23, 24 in Fig. 1). There are other memorial plants grown by politicians in the park, such as Picea pungens 'Glauca' and Sorbus aucuparia 'Pendula'. There are Fagus sylvatica 'Pendula', Salix caprea 'Pendula', Betula pendula 'Youngii', Berberis thunbergii 'Atropurpurea', Prunus cerasifera subsp. pissardii (CarriŠre) Dost 1, Sorbus intermedia (Ehrh.) Pers., Viburnum opulus L. in the so-called arboretum zone and the Guelder-rose Grove zone (laying in 2005), which can act as a means of expressing ideological load due to the crown form, leaf colour, but the inconsistency of their composition and unsuccessful placement within the park negatively affects their perception.

The compositional structure of Peremoha Park includes some controversial moments, they are due to the location of different thematic and function objects. Thus, in the entrance part of the park there is a monument to the Widowed Mother, and in the background of this objects there are attractions for children and other entertainment facilities. In this context, it is worthwhile to note the role of plants to isolating visual links between the contradictory components presented.

Continuing the analysis of plant role in the formation of composition, figurative and symbolic structure of Peremoha Park, it is important to mention thematic flowerbeds which are located along the main park alleyway leading to the Immortality Hill and near the monument "Women of War", which is located next to, as well as individual plants planted during the reconstruction in 2004.

Summarizing the analysis of composition, figurative and symbolic structure of Peremoha Park it is important to mention that along with the clearly inappropriate components of the park environment (entertainment attractions) also there are elements that express the war theme of the park but have an indirect relation to the victory in the Second World War, namely the Guelder-rose Alley to Heroes of Ukraine of the XXI century and the complex composition Border Guard's Alley. The role of woody plants in the formation of figurative and symbolic structure and expressing the park thematic, 
consists in the visual isolation of contradictory to park themes and functions components.

Among the main means of emphasizing themes in the Peremoha Park at the expense of plants can be attributed: the formation of thematic flowerbeds using the symbols ornamentation of the appropriate colours - red, yellow, white; inclusion in the composition of greenery the appropriate crown form, the colour of leaves and inflorescences.

Thus, based on the analysis results as to peculiarities of woody plants using in the formation of figurative and symbolic structure of Kyiv war memorial parks 28 species and 33 cultivars of tree plants among the geenery which are growing on the research objects are proved. They could be use of the indirect means of expression ideological load and park theme due to morphological features of plants, namely the shape and colour of the crown, colouring of branchs, leaves, flowers and fruits, as well as their symbolic meaning.

\section{Analysis of plants influence on the perception and} understanding of park figurative and symbolic structure by respondents

As a result of the Kyiv memorial parks study, it was proved that the most species (25) and cultivars (21) of woody plants wich are used in role of indirect means of expression ideological load are growing in Slava Park. Thus, in the memorial part of the park on the main alley, therefore the formal shape of three-row hedge from Carpinus betulus L., the monumentality and ceremony of the composition is emphasized at the expense of formal planning style, as well as the use of such principles of composition organization as symmetry, magnitude, which are confirmed by the results of the questionnaire. In particular, the signs that the respondents mentioned in the photographs of landscapes, where the hedge from Carpinus betulus L. is present, are primarily sublimated: "magnificent", "solemnly", "bright", "magnitude" and "harmoniously". The mention of the hedge, as a positive feature in such landscapes by respondents, is $10-20 \%$ of their total number. In addition, it should be noted that there is a medium (0.449) correlation between the frequency of sublimed characteristics and the hedge of mentioning respondents as a positive feature of the landscape. Interesting in this context is the fact of same correlation (0.487) between the frequency of mention of the above sublimated characteristics and monuments that, according to Jankovic [13], are a demonstration of collective memory and are used as the main means of expression ideological load of the park and the formation of park information structure.

Therefore of the combination of the frequency of mention to the hedge and the monumental components of park environment, the correlation of these components with sublimated characteristics increases to a strong $(0.721)$, which is a subtext of significant influence of the harmonious combination of plant and architectural components on the perception of figurative and symbolic structure of the park by respondents, as well as formation wholelandscape emotional reaction, which is expressed in the mention of sublimated characteristics in the questionnaire.

The important component of both the compositional and figurative-symbolic structure of the Slava Park is the Hero Cities Alley (location 19 in Fig. 1), formed by Picea pungens 'Glauca', which is often used on the memorial objects of tragic thematic, especially in the parks of the post-Soviet space, that are due to the pyramidal crown shape and blue-coloured needles. Analyzing the role of the alley in formation of figurative and symbolic structure of the park, it is advisable to pay attention to the peculiarities of its perception by respondents, among which $25 \%$ noted the plants as positive elements that influenced their assessment of the summer landscape. In the autumn, the part of mention of Picea pungens 'Glauca', as a positive feature of landscapes, increased to $40 \%$ of the respondents. On the other hand, the influence of Picea pungens 'Glauca' on the formation of solemn mood of landscapes by the designers in this part of the park area was not found among the respondents there is no correlation between the frequency of mentioning the positive role of plants and sublimed characteristics. The tree rows of Sorbus aucuparia 'Pendula' are important component of both the compositional and figurative-symbolic structure in the Slava Park, the shape of its crown emphasizes the tragic theme of the park. These tree rows are located across the slope at two levels of the park and are viewed from a large part of park territory. However, due to the small size of the plants compared with the scale of the park, they are perceived by respondents as components of the park environment, mainly in landscapes of 8 locations (see Fig. 1). Furthermore, the respondents' reaction to these trees is ambiguous, but most clearly reveled in the autumn period. In general, the tree rows of Sorbus aucuparia 'Pendula' is presented in four photographs and in all cases marked by respondents in both positive and negative contexts. In addition, the number of negative references to the Sorbus aucuparia 'Pendula' rows is greater, but a strong correlation (0.889) between the evaluation of the photos and the part of references to plants by respondents as a positive feature of the landscape was found. It is important to note that the part of references to plants in these landscapes in the summer is significantly reduced - in the context of a positive characteristic by $77.8 \%$, and a negative by $61.5 \%$. 
Summarizing the analysis of the peculiarities of the respondents' perception of the landscapes of the Slava Park and the role of woody plants in the formation of the mood according to park theme, as well as the level of understanding of the symbolic content of the object, it is important to focus the attention in plants and plant groups that have a symbolic meaning, but cause of the miss of compositional integrity of their significance in the formation of figurative and symbolic structure is leveled, and the symbols are not "read" by visitors, in particular: Guelder-rose groves, planted in the zone of the Holodomor Victims Memorial Complex and in the north-western part of the park along the walkway to the chapel; memorable tree-planting by politicians - groups of Picea pungens 'Glauca' and Sorbus aucuparia 'Pendula'; single trees of Fraxinus excelsior 'Pendula' and Fagus sylvatica 'Pendula'; irregular groups from Fagus sylvatica 'Pendula', Salix caprea 'Pendula', Betula pendula 'Youngii', Berberis thunbergii 'Atropurpurea', Prunus cerasifera subsp. Pissardii (Carriðre) Dost 1, Sorbus intermedia (Ehrh.) Pers., Viburnum opulus L. et al.

\section{Discussion}

Based on the expert assessment and the analysis of perception peculiarities of park landscapes by respondents, it is advisable to pay attention to the fact that the main principles of plant composition organization of the park environment is to emphasize the memorial elements due to crown form of the plants, less often - based on the perception of crown silhouette, as an indirect means of expressing the ideological load (for example, a weeping crown form for expressing the tragedy of the events, or a conical crown form for solemnity. In general, the main crown forms of tree plants, identified as indirect means of expressing the theme load of the park, include the follows:

- columnar crown shape - Thuja occidentalis 'Columna', Quercus robur 'Fastigiata', Taxus baccata 'Fastigiata', Populus bolleana Louche., Populus nigra var. italica Münchh. et al.;

- conical crown shape - Picea pungens 'Glauca' та ін.;

- rectangular crown shape - hendges from Carpinus betulus L., Ligustrum vulgare L. et al.;

- weeping crown shape - Salix caprea 'Pendula', Fagus sylvatica 'Pendula', Betula pendula Roth. та Betula pendula 'Youngii', Fraxinus excelsior 'Pendula', Salix alba 'Pendula', Sorbus aucuparia 'Pendula', Ulmus carpinifolia 'Camperdownii'.

As to analyzing the use of plants for expressing or highlighting the ideological load of memorial object, it is importance to noting that colour is perceived both as a sign and as a symbol. An example, the yellowish colour became a symbol of the Holodomor in Ukraine in 1932-1933 (it is also known as the Terror-Famine and Famine-Genocide in Ukraine), after the publication of Vasyl Barka novel "Yellow Prince", whose name is an allusion to the biblical horseman on a pale (pale-yellow) horse from Revelation 6:8. At the same time, the yellow colour, like red, is very active and can be used to emphasize attention as a means of highlighting the importance of events, which symbolizes a memorial object. An example of using of yellowish colours in a this context is the colour of branches of hedge from Cornus alba 'Sibirica' in the winter (Fig. 2) near the Holodomor Victims Memorial in the Slava Park.

As to seasonal dynamics of plants, it is important to mention that tree plants can using as indirect means of expressing the ideological load during different periods of the year. Some species of deciduous bushes only in the autumn act this role cause of the red colour of fruits or foliage. Thus, Viburnum opulus L. (see Fig. 2), which emphasizes ideological load of memorial objects of fruits and leaves in the autumnal colour, as well as the symbolic meaning of the plant for Ukrainians, is widespread in war memorial parks. As noted above, the memorial groups and plantings have been created in some research parks, namely: Guelderrose groves - in zones devoted to the Holodomor in Ukraine in 1932-1933 (Slava Park) (see Fig. 2); Guelder-rose Alley to Heroes of Ukraine of the XXI century (a small group of bushes in the Peremoha Park). Also, to the right of the entrance to the high relief composition "The Road of War", on the territory of the National Museum of the history of Ukraine in the Second World War, a rows of bushes from Viburnum opulus L. was created within the Pechersk Landscape Park. In addition, the good using of Spiraea $\times$ vanhouttei (Briot) Zabel in Pechersk Landscape Park on "The Road of the War" is proved, which acts as a protective border for visitors, and therefore the white blossom in the summer and reddish autumn leaves colour, emphasizes the theme of the object. Also the groups from Spiraea japonica L., Euonymus europaeus L., Viburnum opulus L., etc., act as accents in war memorial parks in the autumn. In winter, the plant act as the means of expression of the ideological loading in war memorial parks due to the shape and colour of the crown, branches, fruits: Rhus typhina L., Cornus mas 'Sibirica', Thuja occidentalis 'Sunskit' and others.

The composition of war memorial park in the post-Soviet space has a emphasizes solemn character in the post-Soviet space, which is caused by Cult of the War in the Soviet Union, and shows in the using of such principles of composition organization as formal style, symmetry, magnitude, and colours of the plants. Therefore, for the formation of accents 


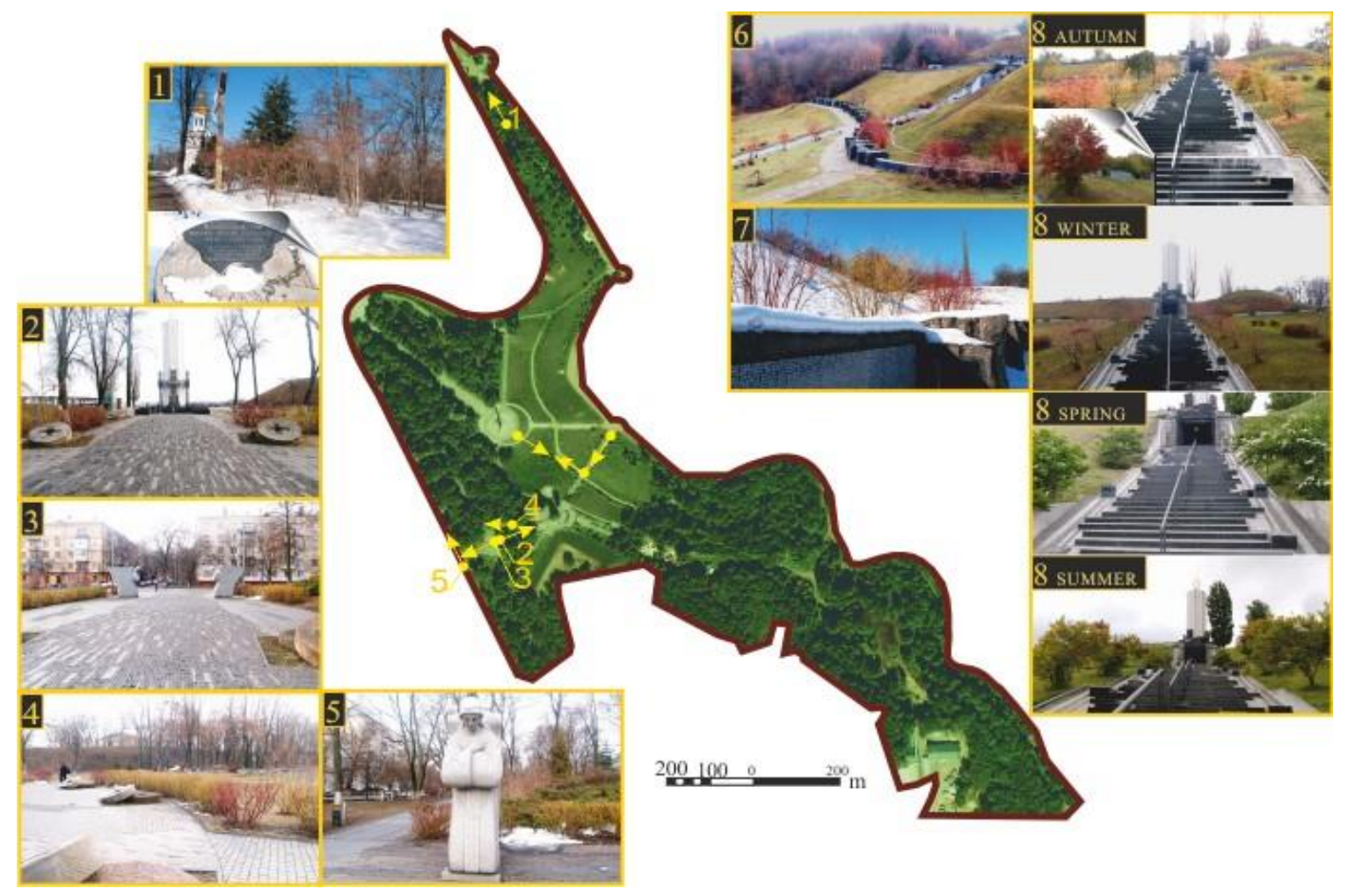

Fig. 2. The peculiarities of the use of plants in the formation of figurative and symbolic structure of the Holodomor Victims Memorial in the Slava Park.

used to beautiful flowering bushes in particular with white inflorescences, which are blooming in the first half of May and the purple foliage plants, both trees and shrubs. It is important to mention that the valuable component of the of memorial parks three-dimensional composition, is coniferous plants, which, due to evergreen colouration and, usually strict forms of habitus, can act as indirect means of expressing the ideological load throughout the year. For example, the main plantings in the territory of the National Museum of the history of Ukraine in the Second World War (within the Pechersk Landscape Park) are groups from Picea pungens 'Glauca', Picea pungens Engelm., Juniperus sabina L., which, due to colour and shape, emphasize the severity of the park theme.

Thus, based on our research results, the peculiarities of the use of woody plants in the formation of figurative and symbolic structure of the war memorial parks of Kyiv were proved and a structural scheme was developed using the semiotic levels of perception of Barabanov [2] (Fig. 3).

Furthermore, the using of plants is the most widely represented in parks, which is based on the sign level of perception (collective unconscious), which is caused by the peculiarities of perception and interpretation of the lines, form and colour of the plant. In particular, within the research parks, both the positive and the negative effects of the shape, size, colour and texture of the plants on the perception of the memorial architectural components were proved (see Fig. 3).
The main negative characteristics of plants and their groups that negatively affect the compositional, informational, ideological and aesthetic meaning of the memorial architectural components of research parks are inconsistency of the composition of plants (background groups, frame plantings, solitaire trees, etc.) and the monument, inconsistency of their scale, closing the view of the monuments by plants.

The positive influence of plants on the formation of compositional, figurative and symbolic structure of the memorial parks of war themes, mainly consists in focusing of attention on memorial architectural objects, highliting their emotional influence and emphasizing the theme of the park through the composition harmonization, as well as the using of the symbolic meaning of plants. The compositional principles of plants using include the formation of view for the memorial, the visual isolation of memorial architectural objects from the rest of the park, highliting the architectural form by matching the shape, colour and texture of the crown of trees and bushes, creating a harmonious background from tree and shrub groups. The most harmonious combination of plants and memorial architectural components is in the Slava Park, which has the strongest influence on the formation of a whole-landscape emotional assessment of park landscapes, according to the park theme, which was confirmed by the results of the questionnaire of respondents. 


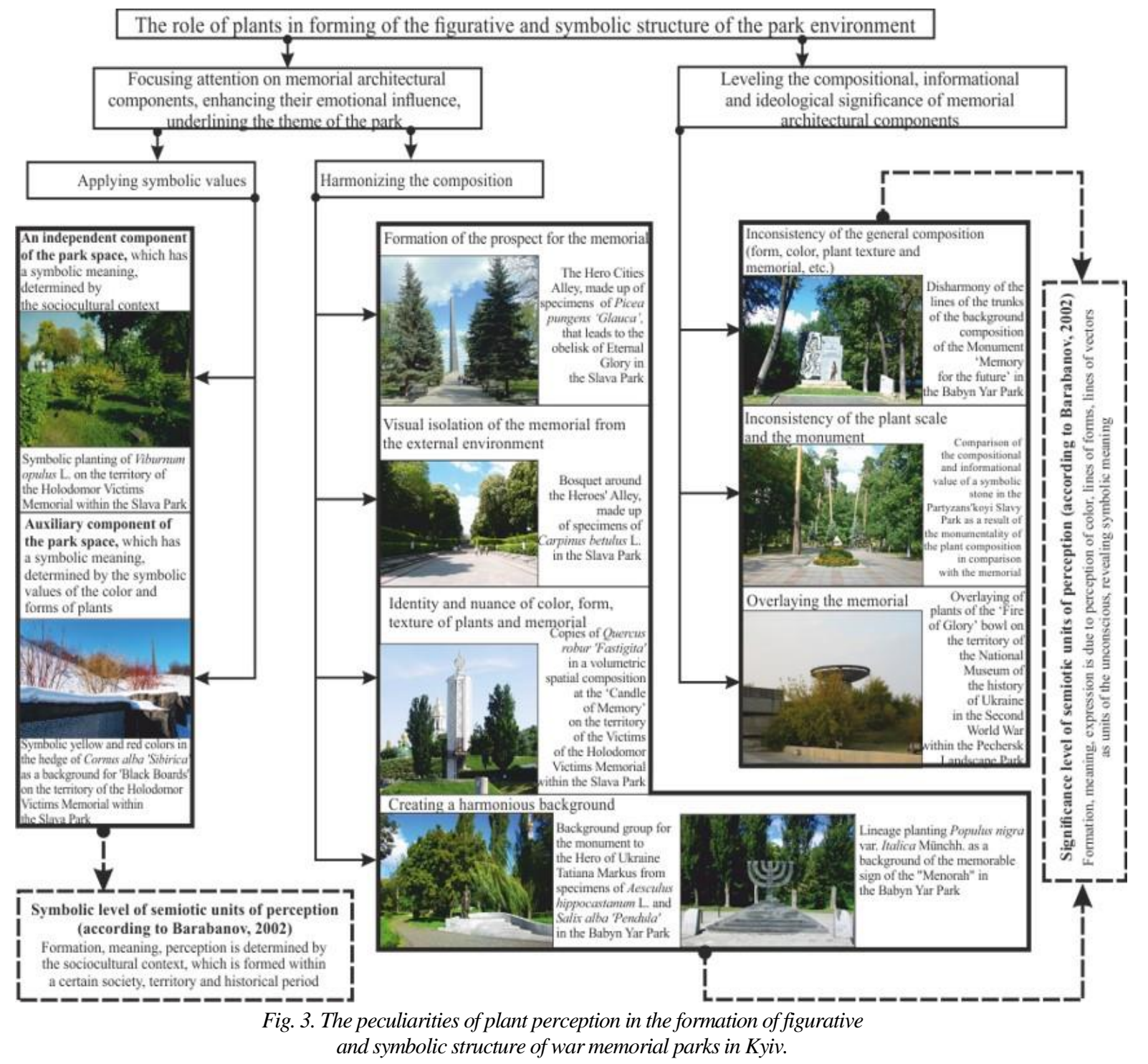

When using symbols in the formation of figurative and symbolic structure of the park, by plants, two approaches to the formation of plant composition are revealed. The first is based on the use of symbolic species of plants for Ukrainians (Viburnum opulus L., Sorbus aucuparia L.), while plant groups are mono-species independent components of the composition. In the second approach, the matching of plants is based on the symbolic meaning of their morphological characteristics (the weeping and pyramidal form of the crown, the red and yellow colour of the leaves, inflorescences, fruits, branches). In this case, the plants are located next to the memorial architectural objects as secondary components to enhance emotional influence and increase the information characteristics of the memorial. This approach to the use of plants for the formation of figurative and symbolic structure of the park is based on the symbolic level of semiotic units of perception, according to Barabanov [2], which is determined by the sociocultural context that is formed within a certain social, historical period and territory. Although the plants that have a certain symbolic meaning, which shows in different levels of semiotic units of perception is proved, the visitor perception of them is ambiguous.

\section{Conclusions}

Summarizing the research results of the interconnections between the plant composition and figurative and symbolic structure of the war memorial park, it is important to accent on the importance of harmonious combination of architectural components and plants for forming a definite emotional reaction of visitors. Since, according to results of the study, it was revealed that along with a large number of plant components within the Slava Park, which were formed in order to create a holistic figurative and symbolic structure of the park, most of them do not have a significant influence on the formation of the necessary emotional reaction from respondents, although affect 
their aesthetic preferences. However, the influence of plants on figurative meaning of the landscape increases significantly when they are harmoniously combined with architectural components, which is confirmed by the results of the questionnaire.

The further work may be aimed at studying the influence of plants on the perception of memorial park landscapes and understanding of their informational and ideological context in the winter period of the year, under the predominance of colour and architectonics of the branches, due to the appearance of the trees and shrubs crowns. Another important aspect of further research is finding of the role of sociocultural influence on the perception of phytocompositions by respondents of different ages, social and ethnic groups.

\section{References}

1. Antrop, M. From holistic landscape synthesis to transdisciplinary landscape management. From Landscape Research to Landscape Planning: Aspects of Integration, Education and Application, 2005, No 12, p. 27-50.

2. Barabanov, A. Man and Architecture: Semantics of Relations. Cloud-Cuckoo-Land, 2002. [online 07.09.2018.] http://www.cloud-cuckoo.net/openarchive/wolke/rus/Themen/021/Barabanov/Barabanov.htm (in Russian).

3. Daniel, T.C., Boster, R.S. Measuring landscape esthetics: the scenic beauty estimation method. USDA Forest Service Research Paper, RM-167, 1976, vol. May (1976), p. 1-61.

4. De La Fuente De Val, G., \& Muehlhauser S, H. Visual quality: An examination of a South American Mediterranean landscape, Andean foothills east of Santiago (Chile). Urban Forestry \& Urban Greening, 2014 , vol. 13 (2), p. 261-271. doi: 10.1016/j.ufug.2014.01.006.

5. Dupont, L., Antrop, M., \& Van Eetvelde, V. Eye-tracking Analysis in Landscape Perception Research: Influence of Photograph Properties and Landscape Characteristics. Landscape Research, 2014, vol. 39 (4), p. 417-432. doi:10.1080/01426397.2013.773966.

6. Fuller, R. A., Irvine, K. N., Devine-Wright, P., Warren, P. H., \& Gaston, K. J. Psychological benefits of greenspace increase with biodiversity. Biology Letters, 2007, vol. 3 (4), p. 390-394. doi:10.1098/rsbl.2007.0149

7. Galev E., Gurkova, M. Galev, N. The role of plants on the impact of cultural and historical monuments. Junior Scientific Researcher, 2016, vol. 2 (1), p. 1-15.

8. Gatalska, N. The communicational and informational value of park environment as an aesthetic object and its impact on the aesthetic view formation of the society. Foresty Ideas, 2018, vol. 24 (12), p. 85-100.

9. Gundersen, V., Frivold, L. Public preferences for forest structures: A review of quantitative surveys from Finland, Norway and Sweden. Urban Forestry \& Urban Greening, 2008, vol. 7, p. 241-258.

10. Gyllin, M., Grahn, P. A semantic model for assessing the experience of urban biodiversity. Urban Forestry \& Urban Greening, 2005, vol. 3, p. 149-161.

11. Hofmann, M., Westermann, J. R., Kowarik, I., \& van der Meer, E. Perceptions of parks and urban derelict land by landscape planners and residents. Urban Forestry \& Urban Greening, 2012, vol. 11(3), p. 303-312. doi:10.1016/j.ufug.2012.04.001

12. Holovey, E.A. Hornova, M. Y. Possibilities for influencing people through the diffuse arrangement of green spaces in urban urban areas. New ideas of the new century: Materials of the International Scientific Conference, FAD TOHU, 2014, vol. 3, p. 22-27. (in Russian).

13. Janković, N. Architectural Terri(s)tories: Jajinci Memorial Park in Belgrade. Journal of Art and Media Studies, 2017, № 12, p. 81-97. doi: 10.25038/am.v0i12.169

14. Jorgensen, A., \& Gobster, P. H. Shades of Green: Measuring the Ecology of Urban Green Space in the Context of Human Health and Well-Being. Nature + Culture, 2010, vol. 5 (3), p. 338-363. doi:10.3167/nc.2010.050307

15. Le Corbusier, L. Novaia epokha v arkhitekture (iz doklada, prochitannogo v Sorbonne 12 iiunia 1924 g. In: Arkhitektura sovremennogo Zapada, Moscow: Izogis, 1932. 186 p. (in Russian).

16. Lindemann-Matthies, P., \& Bose, E. Species richness, structural diversity and species composition in meadows created by visitors of a botanical garden in Switzerland. Landscape and Urban Planning, 2007, vol. 79 (3-4), p. 298307. doi:10.1016/j.landurbplan.2006.03.007

17. Lynch, K. The Image of the City. Cambridge, MA: MIT Press \& Harvard University Press, 1960. 195 p.

18. Oleksiichenko, N. O., Gatalska, N. V., Hrychuk, M. O., Mavko, M. S. Memorial Parks of Kyiv. Monohrafiia. Bila Tserkva: Oleksandr Pshonkivskyi. 2017. 336 p. (in Ukrainian).

19. Osychenko, G. Classification of the aesthetic qualities of the urban environment. New University. 2014. vol. 3-4, p. 28-34. (in Ukrainian).

20. Polat, A. T., \& Akay, A. Relationships between the visual preferences of urban recreation area users and various landscape design elements. Urban Forestry \& Urban Greening, 2015, vol. 14 (3), p. 573-582. doi:10.1016/j.ufug.2015.05.009

21. Rautalin, M., Uusitalo, J., \& Pukkala, T. Estimation of tree stand characteristics through computer visualisation. Landscape and Urban Planning, 2001, vol. 53(1-4), p. 85-94. doi:10.1016/s0169-2046(00)00142-0

22. Shelby, B., \& Harris, R. Comparing methods for determining visitor evaluations of ecological impacts - site visits, photographs, and written descriptions. Journal of Leisure Research, 1985, vol. 17(1), p. 57-67.

23. Thorpert, P., \& Nielsen, A. B. Experience of vegetation-borne colours. Journal of Landscape Architecture, 2014, vol. 9(1), p. 60-69. doi:10.1080/18626033.2014.898834

24. Ulrich, R. S. Human responses to vegetation and landscapes. Landscape and Urban Planning, 1986, vol. 13(1), p. 29-44. doi:10.1016/0169-2046(86)90005-8

25. van den Berg, A. E., Hartig, T., \& Staats, H. Preference for nature in urbanized societies: Stress, restoration, and the pursuit of sustainability. Journal of Social Issues, 2007, vol. 63 (1), p. 79-96. doi:10.1111/j.15404560.2007.00497.x 
26. Vygotsky, L. S. Psychology of Art. Moskow: Pedagogika, 1987. 344 p. (in Russian).

27. Yilmaz S., Özgüner H. \& Mumcu S. An aesthetic approach to planting design in urban parks and greenspaces. Landscape Research, 2018. doi:10.1080/01426397.2017.1415313

\section{INFORMATION ABOUT THE AUTHORS:}

Nadiia Oleksiichenko - Doctor of Agricultural Sciences, Professor, Professor at the Landscape Architecture and Park-Garden Construction Department of National University of Life and Environmental Sciences of Ukraine, 19 Heneral Rodimtsev str., 03041, Kyiv, Ukraine. E-mail: noolex @ bigmir.net

Nadiia Gatalska - PhD of Agricultural Sciences, Associate Professor at the Landscape Architecture and Park-Garden Construction Department of National University of Life and Environmental Sciences of Ukraine, 19 Heneral Rodimtsev str., 03041, Kyiv, Ukraine. E-mail: gatalska.nadiia@ gmail.com

Mariana Mavko - Master of Park Gardening, PhD student of Landscape Architecture and Park-Garden Construction Department of National University of Life and Environmental Sciences of Ukraine, 19 Heneral Rodimtsev str., 03041, Kyiv, Ukraine. E-mail: marianna.kotsan@ gmail.com

Oleksandr Ostapchuk - PhD in Agricultural Sciences, assistant professor at the Departament of Forestry, The Faculty of Forestry and Landscape Gardening of Uman National University of Horticulture, 1 Institutska str., 20300, Uman, Ukraine. E-mail: ostapchyk1958@gmail.com

Kopsavilkums. Rakstā ir izklāstîti pētījumu rezultāti par augu lomu kara memoriālo parku figurālās un simboliskās struktūras veidošanā. Pētījums pierāda, ka kokaugi var būt kā simbolisks ideologiskās izpausmes veids atškirīgos gadalaikos. Dažas lapu koku un krūmu sugas šo lomu spēlē rudenī ne tikai augḷ sarkanās krāsas dēl, bet ietverot arī lapotni, jo īpaši Viburnum opulus L., kas ir izplatīts Kijevas kara memoriālajos parkos. Ziemā vainaga, zaru un aug̣̣u forma un krāsa (Rhus typhina L., Cornus mas 'Sibirica, Viburnum opulus L., Sorbus) veido kompozicionāli spēcīgu vizuālās izteiksmes valodu.

Pamatojoties uz Kijevas memoriālo parku ekspertu novērtējuma rezultātiem, tiek atklātas augu koksnes izmantošanas īpatnības Kijevas kara memoriālo parku figurālās un simboliskās struktūras veidošanā. Strukturālā shēma tiek pakārtota atbilstoši semantiskai uztverei, kā norādīts Barabanova pētījumā (2002). Tiek atklāts, ka augu izmantošana ir visizplatîtākā parkos, kas balstās uz krāsas un formas uztveri, ko veido augu dendrologiskās īpatnības. Pêtītajos parkos tika atklāts, ka gan pozitīvā, gan negatīvā kompozicionālā "scenārija" izspēle uz augu formu, izmēru, krāsu un tekstūru ietekmē memoriālās arhitektūras komponentu uztveri. Izmantojot kokaugu simbolus parka struktūras veidošanā, atklājas divas pieejas augu sastāva veidošanai. Pirmais ir balstīts uz simbolisku Ukrainas augu sugu izmantošanu (Viburnum opulus L., Sorbus aucuparia L.), savukārt augu grupas ir vienas sugas kompozīcionālā sastāvdaḷa. Otrajā piejā augu dendrolog̣isko īpatnību izvēle balstās uz to morfoloğisko īpašību simbolisko nozīmi. Šajā gadījumā augi atrodas blakus piemiņas arhitektūras objektiem kā sekundārie komponenti, lai palielinātu emocionālo spēli un kāpinātu piemiṇas zonas informāciju. Minētā pieeja augu izmantošanai parka figurālās un simboliskās struktūras veidošanā ir balstīta uz vizuālās uztveres līmeni, ko nosaka sociālkulturālais konteksts, kas veidojas noteiktā valsts vēsturiski politiskajā un sociālekonomiskajā laika posmā. 